\title{
Resignations rock mathematics institute
}

Geoff Brumfiel, Baltimore

A string of resignations at the Massachusetts-based Clay Mathematics Institute (CMI) has left some top mathematicians uneasy about the future of one of the discipline's most benevolent backers.

Last November, CMI president Arthur Jaffe — a mathematical physicist at Harvard University and recent past president of the American Mathematical Society (AMS) resigned, with two other members of the four-strong scientific advisory board.

Concerns about the resignations were voiced at the AMS annual meeting in Baltimore, Maryland, on 15-18 January. "I'm very worried," says Peter Sarnak, a mathematician at both Princeton and New York universities. "For pure mathematics, the CMI has been a godsend. If it disappeared, it would be very serious."

The CMI was set up in 1998 by Landon Clay, a local financier and philanthropist, with Jaffe as its first president, to fund innovative research and raise the profile of mathematics. It is perhaps best known for offering prizes worth US\$1 million apiece to anyone who could solve seven famous mathematical problems (see Nature 405, 383;2000).

The institute also provided about $\$ 3$ million in grants and awards worldwide last year. "The Clay has raised our visibility and provided a significant amount of resources to mathematicians," says Hyman Bass of the University of Michigan, the current AMS

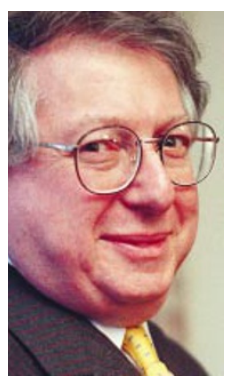

president."It has become a major part of the field. Clearly, the fact that a significant part of the advisory board has jumped ship implies something has gone badly awry."

The scientific advisory board "has made some very careful decisions on what is needed Arthur Jaffe: walked for mathematics in the out of the institute future", says Jennifer in November. Chayes, co-manager of the theory group at Seattle-based Microsoft Research.

Jaffe says that he was told in November he would have to leave at the end of 2002, but that no reason was given for the request. In the meantime, he says, the board of directors proposed constraints on his interactions with other members of the science board that made it impossible for him to do his job.

Eric Woodbury, the CMI's chief administrator, maintains that Jaffe's three-year term as CMI president had simply expired. Jaffe disputes this. "To my knowledge, there was no term," he says. There is no mention of a term in the CMI's by-laws.

The other board members who resigned were Edward Witten, of the Institute for Advanced Study at Princeton, and Alain Connes, of the Collège de France in Paris. Both are recipients of the discipline's highest honour, the Fields medal. A copy of Connes' resignation letter, obtained by Nature, cites Jaffe's removal as his reason for quitting. "The main reason is that I disagree with the dismissal of Arthur Jaffe as president and do not want to assume any responsibility for this move," Connes wrote.

Woodbury says that the institute is undergoing a normal transition. "It is expected there will be turnover from time to time," he says. Three new members, including two Fields medal winners, have agreed to join the scientific board, he says. Woodbury expects a new president to be appointed this year. "Our level of programming and research support will be continued," he says. "And the \$7 million in prizes won't go away.”

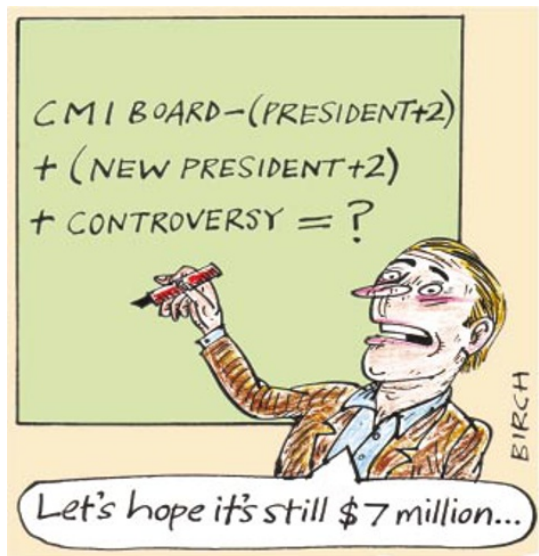

\section{Researcher uncovers truth behind wartime security slur}

\section{Rex Dalton, San Diego}

Austrian-born oceanographer Walter Munk has never forgotten the false allegations of Nazi sympathies that prompted the US government to strip him and his mentor of their security clearances six decades ago.

A disclosure of government files has now confirmed the thinness of the case prepared against the two by J. Edgar Hoover, director of the Federal Bureau of Investigation (FBI).

Munk is keen to tell his story to today's scientists - some of whom may also find their loyalties questioned on the basis of their ethnic origins. He has recently published an account of the events

(Oceanography 15, No. 4, 7; 2002), after obtaining his case files under a Freedom of Information Act request.

Munk and his Norwegian mentor, Harald Sverdrup, lost their clearances in 1942, while working at the Scripps Institution of Oceanography (SIO) in La Jolla, California. The duo was involved in a wave-prediction model that was crucial in aiding the US
Navy's first amphibious landing of the war in North Africa.

Sverdrup, a prominent Norwegian oceanographer who was the SIO's director from 1936 to 1948 , never again received full security clearance, although he acted as a government consultant on military projects. He died in Norway in 1957, never knowing why his clearance had been withdrawn.

Munk, now aged 85, won back his military security clearance soon after it was pulled - helped by leading scientists who wrote to the government on behalf of the duo - and is still a senior SIO researcher.

Records held by the Navy and FBI show that the clearances were withdrawn as a result of statements from two now-dead faculty colleagues at Scripps bacteriologist Claude ZoBell and biochemist Denis Fox - and of some other acquaintances.

Munk and Naomi Oreskes, an Earthscience historian at Scripps who has also written about the affair, believe that the investigation may have been driven by grudges arising from Sverdrup's leadership of Scripps. There was no evidence of Nazi collaboration or misdeeds in the files, only records of the informants' testimony, possibly based on the fact that the two were foreign and spoke German.

Munk was "amazed" on reading the sum of the evidence against him and Sverdrup, he says. The investigating agencies "deprived the country of needed talents and put the careers of several individuals in jeopardy", Munk writes in his article.

Oreskes and Ronald Rainger, a historian at Texas Tech University in Lubbock, asserted in an article on the affair (Stud. Hist. Phil. Mod. Phys. 31, 309-369; 2000) that the probe helped to create a framework for subsequent government investigations of physicists, including Robert Oppenheimer, engaged in the Manhattan Project to build the atom bomb. "In matters of loyalty, the burden of proof was on the accused, not the accuser," they say. 